\title{
A PROPER MECHANICAL SYSTEM FOR SOWING WHEAT CROP IN SEMI-ARID SOIL
}

\author{
Abo-EL-Naga M.H. ; M. M. Abdel-Galil ${ }^{2}$ and A. S. EL-Ashrey ${ }^{1}$
}

\section{ABSTRACT}

Different mechanized systems were investigated to select the proper machinery system for sowing and grain covering operations of wheat crop in semi-arid soil. The mechanized sowing systems included using the bandwidth distributor $(B)$, and fertilizer spreader $(F)$ machinery techniques. While, the grain covering operations were performed using rotary tiller $(R)$, and chisel plow $(P)$ each followed by lever $(L)$ machinery techniques

Measurements of the revealed properties in top soil layer, grown plants characteristic crop yield, the system energy consumptions, , and system cost, were taking into consideration to compare between the tested field treatments.

The gained results showed that:-

- Applying the bandwidth distributor $(B)$ to perform wheat sowing, and using the rotary tiller followed by a lever to perform grain covering operation revealed lower soil compaction (17.61\%) and better soil profile leveling $25.26 \%$ lead to increase number of plants $\left(347.60 / \mathrm{m}^{2}\right.$ and improve grain germination percent $(85.95(\%)$ and provided the heights crop grain yield (2.834 ton /fed).

-Generally the results indicated that, sowing with fertilizer spreader, and grain covering with. chisel plow followed by lever gave the highest energy value (19.5 kW.h/fed) While lowest consumed energy (8.1 $k W . h / f e d$ )with hand broadcast and lever, was performing using rotary tiller followed by lever machinery techniques demolishes the differences in the energy consumed by the sowing system.

- Performed grain covering using rotary tiller $(R)$, or chisel plow $(P)$ each followed by lever machinery techniques have high effect on the system cost. But it should be denoted that operation at high speed, and large width will decrease cost per fed, and demolish the cost differences between investigated covering systems.

\section{INTRODUCTION}

owadays, the loaf of bread represents the greatest problem
because of the insufficiency of wheat production; the mechanical
systems of sowing participate in improving wheat productivity.

1 Senior Researcher in Agric. Eng. Res. Inst. Agric. Res. Centre

2 Researcher in Agric. Eng. Res. Inst. Agric. Res. Centre

Misr J. Ag. Eng., April 2009 
EL-Sayed (1983) found that bulk density decreased after tillage treatments, on the other hand, the total porosity and void ratio increased. Abou EL-Kheir and abdel- Ghaffar (1985) found that the speed and depth are directly proportional to the soil quality by increasing the rotary knives speed with $40 \%$, the bulk density and penetration resistance decreased by 1.086 and 1.048 times respectively. Heege (1986) reported that the bandwidth and band sowing method increased the crop yield in comparison with drill method. Abdel-Wahab (1994) studied the effect of a combined chisel plow and wooden leveler utilization (under conditions of distance and mass) on soil bulk density, soil penetration resistance, slip, fuel consumption, draft, consumed energy, time requirement and cost of grain bed preparation compared to the conventional method by using two ways chiseling followed by wooden leveler. He found that the grain bed preparation by combination of (plow +leveler) at distance of $2 \mathrm{~m}$ between them and leveler mass of $285 \mathrm{~kg}$ under $3.1 \mathrm{~km} / \mathrm{h}$, travel speed remarked acceptable results of bulk density, soil penetration resistance, energy requirement and total cost of grain bed preparation. EL-Hanafy et al. (1995) found strong relationship between yield and number of grain sowings at depth $1-2 \mathrm{~cm}$ from one side and both soil bulk density and soil mean weight clod diameter from the other side. Also, the use of chisel plow followed by rotary tiller can be recommended because it gave the best grain bed preparation in terms of lowest value of mean soil clod diameter and the highest yield of barley. Abdou (1996) illustrated that the use of chisel plow two passes at $18 \mathrm{~cm}$ depth gave grain and straw yields higher than that of the same operations at $10 \mathrm{~cm}$. the use of disk harrow or rotary tiller after chisel plow gave higher yield of grain and straw compared with chisel plow two passes for wheat crop. Using a rotary tiller plow for $10 \mathrm{~cm}$ depth gave a higher barely yields (grain- straw). Also using band sowing with distributor flutes gave higher yields. Abd Alla et al. (1999) mentioned that the grain-bed preparation which applied rotary tiller after chisel plow followed by scraper and sowing wheat by using drilling machine which provided with flat distributor, gave the highest wheat yield and consumed low energy. While the lowest yield was Misr J. Ag. Eng., April 2009 
obtained by using chisel plow two passes and band sowing by grain drill machine without furrow openers. EL-Saharigi et al. (2001) found that the optimum grain emergence range of $(95.83-96.82 \%)$ and highest grain productivity $(1.5-1.95$ ton/fed $)$ were obtained by using straight band sowing by grain drill with straight distributors and laser landleveling. Helmy et al. (2001) found that the rotary plow exhibit lower fuel consumption and power requirements compared with the chisel plow (one pass), chisel plow (two passes) and moldboard plow followed by disk harrow respectively. Morad et al. (2002) developed a simulation model of the spinning disc performance of the broadcasting fertilizers. They found that the experimental results as well as simulation model results reveal that the predicting operational parameters (feed radius of 75 $\mathrm{mm}$, spinner radius of $250 \mathrm{~mm}$ and spinner rotating speed of $480 \mathrm{rpm}$ ) improve the uniformity of fertilizer distribution. Moussa et al. (2004) found that the heist yield of barley crop was obtained at plowing depth 10 $\mathrm{cm}$ by using chisel plow (two passes) followed by disk harrow one pass under grain drill system. Kishta and Eliwa (2005) developed and evaluated a portable grain and fertilizers spreader. They found that the highest uniformity coefficient of distribution of $95.8 \%$ is noticed at beater speed of $500 \mathrm{rpm}$ when using the electrical device in the wheat field.

The present study aimed to select the proper mechanizing systems for sowing wheat crop in semi-arid soil. The selection was based on determining the revealed properties of top soil layer, grown plants characteristic and distribution uniformity the system energy consumptions, crop yield, and system cost.

\section{MATERIALS AND METHODS}

To evaluate the investigated mechanized systems for sowing, and grain covering operations of wheat crop in semi-arid soil, the experiments were carried out during two sequences winter seasons 3007/2008 after rice crop at a private farm in Nawasa EL-Gheet village, Dakahleia Governorate. The tested crop variety was (Sakha 93). The experimental soil was claysilt loam with average soil properties of moisture content of $22 \pm 0.9$, bulk density $1.59 \pm 0.09 \mathrm{gr} / \mathrm{cm}^{3}$ and soil roughness of $29.52 \pm 0.71 \%$. Its Misr J. Ag. Eng., April 2009 
mechanical analysis revealed that soil fractions, (\%) are 45.3, 30.2 22.5, 2.00 for clay, silt, fine sand, and coarse sand respectively.

\section{Materials}

\section{1-The deduced sowing machinery}

The mechanized sowing systems included using the bandwidth distributor (B), and fertilizer spreader (F) machinery techniques.

The bandwidth distributor unit was developed and locally made by AboEL-Naga (2006). It was an air - carrier knapsack sprayer and developed for distribution small grains using air pressure system. That unit included 14 holes pipe of about $150 \mathrm{~cm}$ length, and $3.81 \mathrm{~cm}$ diameter as shown in Fig. (1). The pipe could be adapted and attached direct to a carrier knapsack sprayer tube, to be used at working width of about $150 \mathrm{~cm}$.

The investigated Fertilizer spreader was a Massy Ferguson type, that made in (USA). The spinner radius of that spreader was $250 \mathrm{~mm}$ and spinner rotating speed of $480 \mathrm{rpm}$ ), while working width was $300 \mathrm{~cm}$. The main components, and dimensions of the used fertilizer spreader are sketched and shown in Fig. (2).

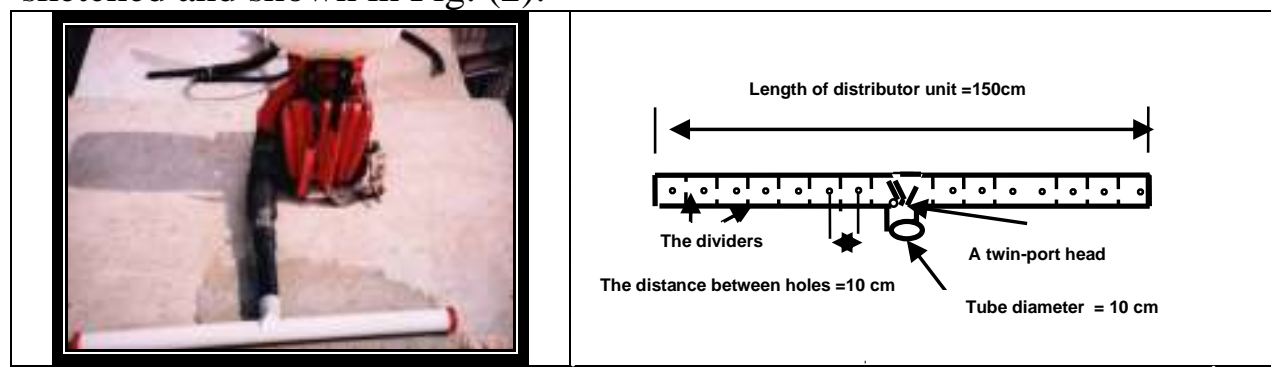

Fig. (1): Distributor unit and Tube sketch used for wheat grains sowing
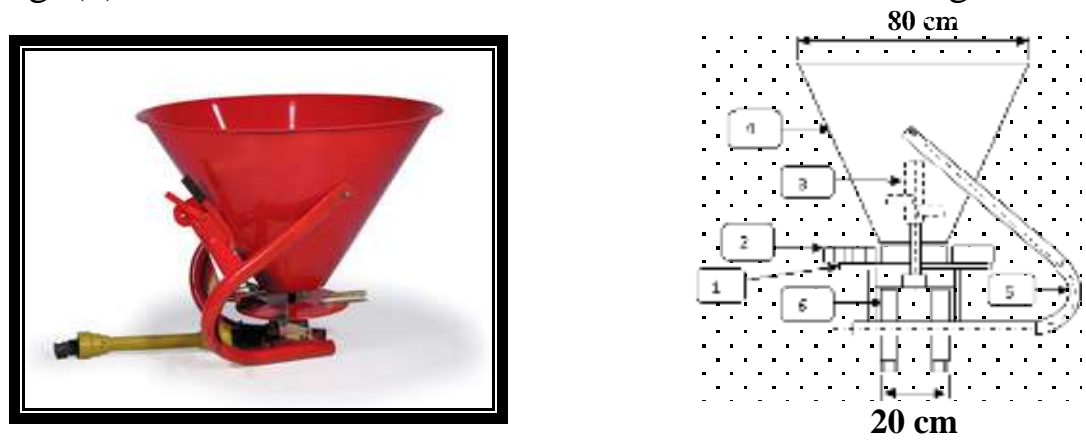

1 Spreading Plates 2 Blades

4 Hopper 5 Frame

3

6
Agitator Shaft

Transmission Gear Box

Fig. (2): The main components, and dimensions of the used fertilizer spreader.

Misr J. Ag. Eng., April 2009 


\section{2- The deduced grain covering machinery}

The investigated grain covering operations were performed using rotary tiller and chisel plow each followed by lever. The used chisel plow was a mounted one and having 5 tines. It was locally fabricated, and adapted for a theoretical working width of $125 \mathrm{~cm}$. The used rotary plow was also mounted plow, It was made in Turkish, and having, 30 L-shape rotary blades, which were fixed on the rotating shaft in 6 groups to obtain theoretical working width of $125 \mathrm{~cm}$.

The deduced land leveler was locally fabricated, and adapted to obtain theoretical working width of $1.5 \mathrm{~m}$.

\section{3-The used Tractor:}

A Kubota (L285) tractor with an engine of $25 \mathrm{hp}(18.64 \mathrm{~kW})$ and PTO speed of $540 \mathrm{rpm}$, was used for powering the investigated machinery.

\section{Experimental Procedures}

To perform the different sowing and grain covering systems an experimental area of about 1.5 feddan was divided into three equal main plots according to the used planting system each main plot was of $(72 \mathrm{x}$ $28 \mathrm{~m}$ ) shown in Fig. (3).

The experimental treatments were carried out after 16 days from the soil tillage and irrigation and replicated three times according to the covering speed in completely randomized block design.

\begin{tabular}{|c|c|c|c|c|}
\hline \multirow{2}{*}{\multicolumn{2}{|c|}{$\begin{array}{l}\text { The experimental } \\
\text { treatments }\end{array}$}} & \multicolumn{3}{|c|}{ Sowing systems } \\
\hline & & $\begin{array}{l}\text { Manual } \\
\text { sowing } \\
\text { (M) }\end{array}$ & \multirow{2}{*}{$\begin{array}{c}\begin{array}{c}\text { Sowing with the } \\
\text { distributor unit } \\
\text { (B) }\end{array} \\
\text { BPL }\end{array}$} & \multirow{2}{*}{$\begin{array}{c}\begin{array}{c}\text { Sowing with the } \\
\text { fertilizer spreader } \\
\text { (F) }\end{array} \\
\text { FPL }\end{array}$} \\
\hline 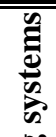 & $\begin{array}{c}\text { chisel plow } \\
\text { one pass + } \\
\text { leveler }\end{array}$ & MPL & & \\
\hline 更 & $\begin{array}{l}\text { rotary tiller } \\
+ \text { leveler }\end{array}$ & MRL & BRL & FRL \\
\hline 芑 & $\begin{array}{c}\text { Traditional } \\
\text { only leveler } \\
\text { (Datum) }\end{array}$ & ML & BL & FL \\
\hline
\end{tabular}

Fig. (3): Layout of the experimental treatments on the field plots.

The Feeding rate of wheat grain was adjusted for both sowing machines at $70 \mathrm{~kg} / \mathrm{fed}$ and also for manual sowing treatments under study. Each Misr J. Ag. Eng., April 2009 
main plot was divided into three subplots, each of ( $28 \times 24 \mathrm{~m}$ ) according to the used grain covering system. The first main plot of was planted manually $(\mathrm{M})$ at average forward speeds of an average about $1.21 \mathrm{~km} / \mathrm{h}$. The second main plot was planted using the developed distributor unit (B) at average forward speed of about $2 \mathrm{~km} / \mathrm{h}$. And the third main plot was planted using the fertilizer spreader $(\mathrm{F})$, the sowing treatments namely $\mathrm{M}$, $\mathrm{B}$ and $\mathrm{F}$ were carried out after 26 days from the soil irrigation and replicated three times in completely randomized block design

In additions, the grain covering operations was accomplished using three different systems. In the first subplot the grain was covering using chisel plow one pass + leveler (PL). In the second subplot the grain was covering using + rotary tiller + leveler (RL). And In the third subplot the grain was the grain covering using Traditional covering method (only leveler, L) it was considered as datum (control treatment).

The Kubota tractor was adapted to drag both combined covering units (chisel + lever, and rotary plow+ lever) at 2nd gear low fuel throttle (average forward speed of $2.66 \mathrm{~km} / \mathrm{h}$ ), 2nd gear fully throttle (average forward speed of $3.52 \mathrm{~km} / \mathrm{h}$ ), and $3^{\text {rd }}$ gear half throttle (average forward speed of $4.72 \mathrm{~km} / \mathrm{h}$ )

\section{Methods of Measurements}

Measurements of the revealed properties of top soil layer, grown plants characteristic and distribution uniformity crop yield, the system energy consumptions, and system cost, were taking into consideration to compare between the tested field treatments

\section{1-Measurements in the revealed top soil layer properties}

These measurements were carried out 15 after performing each tested sowing/grain covering system. The measurements included :- soil bulk density and soil roughness.

\section{a)Soil bulk density (B.D), and porosity(SP):}

It was determined at three different depth ranges (0-10), (10-20) and (20$30 \mathrm{~cm}$ ) before and after each treatment according to Black et al. (1965) and Essan (1997).by the following formula; 


$$
B d=\frac{D m}{T v}
$$

Where: $B \cdot d=$ Soil bulk density, $\mathrm{g} / \mathrm{cm}^{3} \quad T v=$ Total soil volume, $\mathrm{cm}^{3}$.

$$
D_{m}=\text { dry mass, } \mathrm{g} \text {. }
$$

The change percentage in the average soil bulk density for the top layer that $(\Delta \mathrm{p}, \%)$ due to the applications of each investigated was calculated as follows:

$$
\Delta p=\frac{p_{1-} p_{2}}{p_{1}} \times 100 \ldots \ldots \% \ldots \ldots \ldots . .(2)
$$

Where;

$$
\boldsymbol{P}_{1}, \boldsymbol{P}_{2}=\text { soil bulk density before and after system applications. }
$$

\section{b)Measurements of soil roughness}

In fact the soil profile measured is very important with respect to the machinery wheel movement and traffic during harvesting and post harvesting operations. However a locally made profile meter was used to measure the profile of top soil layer before and after accomplishing each system. The revealed soil roughness In each plot was determined as follows:-

In each profile meter positions, the standard deviation on the graph paper readings (at a constant $5 \mathrm{~cm}$ transect distance) could be estimated using the following equation:

$$
S=\left[\frac{\frac{\sum X^{2}-\left(\sum X\right)^{2}}{N}}{(N-1)}\right]^{0.5}
$$

Where:

$\mathrm{S}=$ Standard deviation $(\mathrm{cm})$;

$\mathrm{X}=$ Distance between a reference horizontal surface and soil surface $(\mathrm{cm})$, and

$\mathrm{N}=$ Number of readings.

The soil surface roughness ( $\mathrm{R}, \%)$ could be calculated using the following equation: according to Gaheen et al. (1978), 


$$
\mathbf{R}=100 \log s
$$

Where:

$$
\begin{aligned}
& \mathrm{R}=\text { Soil surface roughness }(\%), \text { and } \\
& \mathrm{s}=\text { Standard deviation of readings }(\mathrm{cm})
\end{aligned}
$$

To compare the soil roughness resulting from the nine compared systems, the change in soil roughness percentage $(\mathrm{R} \%)$ could be calculated as follows:

$$
C h=R_{a}-R_{b}
$$

Where:

$$
\begin{aligned}
& \mathrm{Ch}=\text { Change in soil roughness, }(\%) \\
& \mathrm{Rb}=\text { Soil roughness before system application, } \% \\
& \mathrm{Ra}=\text { Soil roughness after system application, } \%
\end{aligned}
$$

\section{2- Measurements on grown plants characteristic}

The number of plants/m2, and germination percent $(\mathrm{g}, \%)$ were measured and determined two weeks after sowing and irrigation operations. The ( $g$, $\%)$ was calculated as follows:-

$$
g(\%)=\frac{b}{d} \times 100
$$

Where:

$\mathrm{b}=$ Average number of grown plants of grown plants per $\mathrm{m}^{2}$

$\mathrm{d}=$ Average delivered grain numbers per $\mathrm{m}^{2}$

\section{3-The system energy consumptions}

The power consumed by each investigated system using the fertilizer spreader and using plow+ lever covering operations was calculated using the measured fuel consumption by the Kubota tractor during the operation. In addition, the power required to operate, the distributor unit (carrier knapsack sprayer) was at 6000 r.p.m as $3.73 \mathrm{~kW}$ and reduced until to $\mathrm{kW} 2$ at low r.p.m, while the human power was assumed as 0.1 kw (Kienzle (2006)

The following formula was used to estimate equivalent power by using the measured fuel consumption for the mechanized system according to Hunt, (1983), and Rangasamy et. al., 1993 as follows: 


$$
\boldsymbol{P}=\frac{\boldsymbol{F C}}{3600} \times \boldsymbol{\rho} . \boldsymbol{f} \times \boldsymbol{L C} \boldsymbol{V} \times 427 \times \boldsymbol{\eta}_{\boldsymbol{t h}} \times \boldsymbol{\eta}_{\boldsymbol{m} e \boldsymbol{c}} \times \frac{1}{75} \times \frac{1}{1.36} \ldots ., \boldsymbol{K W}
$$

Where:

$\mathrm{FC}=$ fuel consumption, $\mathrm{L} / \mathrm{h}$,

$\rho_{. \mathrm{f}}=$ density of fuel, $\mathrm{Kg} / \mathrm{L}($ For diesel $=0.85)$,

L.C.V= calorific value of fuel $(10000 \mathrm{Kcal} / \mathrm{Kg})$,

$427=$ thermo-mechanical equivalent, $\mathrm{J} / \mathrm{Kcal}$,

$\eta_{\text {th }}=$ thermal efficiency of engine $(\approx 35 \%$ for diesel engines $)$,

$\eta_{\text {mec }}=$ mechanical efficiency of engine $(\approx 80 \%)$.

While, the system energy consumptions was estimated using the following equation: -

While, the energy required for each mechanized system was estimated using the following equation: -

While, the energy required for each mechanized system was estimated using the following equation: -

$$
\text { System.energy consumption } \left.(k W . h / \text { fed. })=\frac{\text { Power requirement }(k W)}{\text { Effective field capacity }(\text { fed } / h)} \ldots \ldots . . .8\right)
$$

\section{5 -The system cost}

The hourly cost for the each tested machine in each investigated system operation was determined using the following equation, (Hunt, (1983))

$$
\text { Hourly cost }=P / H(1 / A+I / 2+T+R)+(0.9 W . S . F .)+M / 144, \text { L.E./h .....(9) }
$$

Where:

$\mathrm{P}=$ price of machine, L.E, $\quad \mathrm{H}=$ yearly working hours, h / year,

$\mathrm{A}=$ life expected of machine, year, I= interest rate / year,

$\mathrm{T}=$ taxes, over heads ratio, $\quad \mathrm{R}=$ repairs and maintenance ration,

$0.9=$ factor accounting for lubrication, $\mathrm{W}=$ power, $\mathrm{hp}$,

$\mathrm{S}=$ specific fuel consumption $(\mathrm{L} / \mathrm{hp} . \mathrm{h}), \mathrm{F}=$ fuel price, $\mathrm{L} . \mathrm{E} . / \mathrm{L}$,

M/144= monthly wage ratio, L.E

The system operating cost per Fed was determined using the following equation:-

$$
\text { System operating cost }=\frac{\text { Total hourly cost }(\mathrm{LE} / \mathrm{Fed})}{\text { system actual field capcity }(\mathrm{Fed} / \mathrm{h})}
$$


It should be denoted that the total hourly cost included both manual, and machinery costs. The system work rates excluded also both manual, and machinery operations in the system

\section{RESULTS AND DISCUSSION}

The obtained results will be discussed under the following headings:

\section{1-The revealed top soil layer properties}

\section{* The revealed Soil bulk density;}

Fig. (4) shows the revealed soil bulk density as affected by the investigated mechanized systems for wheat sowing, and grain covering operations at different forward speed. While, Fig. (5) illustrates the change in revealed in soil bulk density due to the investigated systems, and related to soil bulk density before system applications.

It can be seen that the revealed soil bulk density was generally, affected by the investigated sowing, and grain covering systems of wheat crop in semi-arid soil, Referring Fig. (4), it may be stated that sowing with the fertilizer spreader)machinery techniques (F) revealed more compacted soil $\left(1.451 \mathrm{~g} / \mathrm{cm}^{3}\right)$ than using $(\mathrm{B})$ the bandwidth distributor $\left(1.398 \mathrm{~g} / \mathrm{cm}^{3}\right)$ or (M) manual sowing $\left(1.406 \mathrm{~g} / \mathrm{cm}^{3}\right)$.
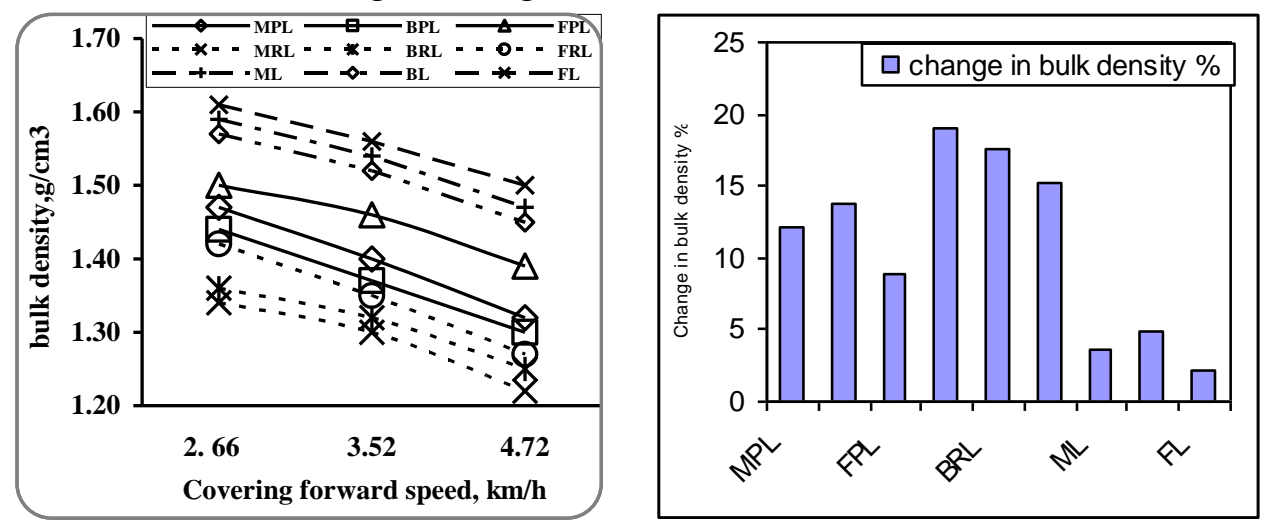

Fig. (4) the revealed soil bulk density as Fig. (5) the change in revealed soil bulk density affected by the investigated systems due to the investigated systems Regarding the of effect of covering operation speed on the soil bulk density, it can be seen that in general increasing operation speed revealed lower soil bulk density by about $6: 10 \%$. The highest reduction percent as 
the operation speed increased was accomplished rotary tiller + leveler (RL), while, the lowest was accomplished traditional method (only leveler, L).

While referring Fig. (5) the effect of the investigated grain covering systems, it may be stated that covering using (rotary tiller + leveler) (RL). Exhibited the lowest value $\left(1.314 \mathrm{~g} / \mathrm{cm}^{3}\right)$ and the highest reduction effect $(17.3 \%)$ on soil bulk density with respect to the before applying the system. That trend followed by using(chisel plow one pass + leveler) (PL) which exhibited bulk density of $1.406 \mathrm{~g} / \mathrm{cm}^{3}$, and reduction effect of (11.6\%).Came at the end covering with traditional method (only leveler, L). That resulted in bulk density of $\left(1.534 \mathrm{~g} / \mathrm{cm}^{3}\right.$ and reduction effect of $(3.5 \%)$

\section{The revealed soil profile roughness $(\mathrm{R} \%)$ :}

The average soil profile roughness $\%$ resulted in the nine investigated plots (systems) are plotted in Fig. (6) against covering operation speeds. While, Fig. (7) presents the changes (\%) that revealed in soil roughness due to applying each systems, compared to soil roughness $29.52 \%$ before system applications.

It could be easily noticed that the lowest changes in soil roughness are accomplished the plots used traditional covering method (only leveler). On the other side, the highest changes in soil roughness was accomplished the plots used rotary tiller + leveler (RL).

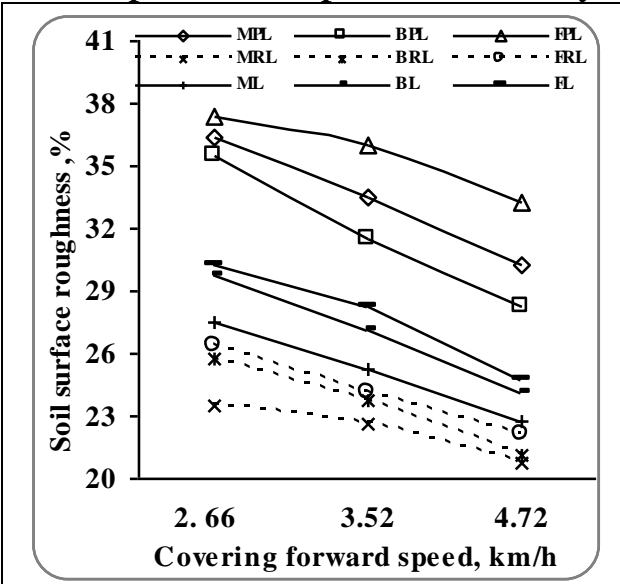

Fig. (6) The revealed soil profile roughness \% as affected by the investigated systems.

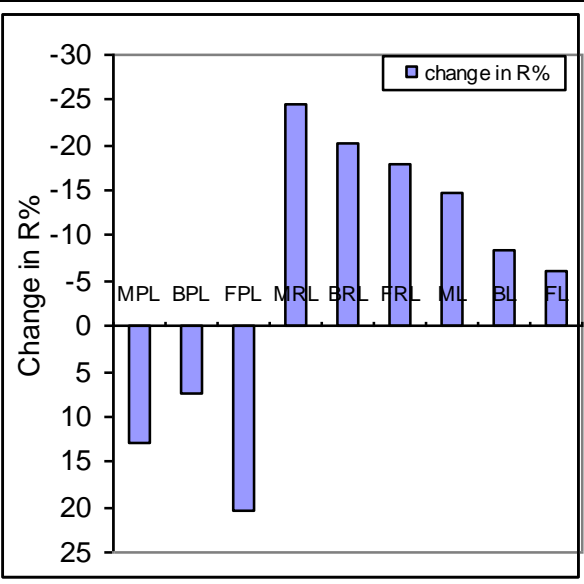

Fig. (7) The change in revealed soil profile roughness $\%$ due to the investigated systems.

Misr J. Ag. Eng., April 2009 


\section{2-The grain germination $(\%)$, and yield}

\section{*...The germination percent $(\%)$}

Data in Figs. (8) and (9) show the resulted number of plants $/ \mathrm{m}^{2}$, and the estimated germination percent $(\%)$ as affected by the investigated systems. It can be in general noticed that the applied system (BRL) that exhibited lower soil compaction and better soil profile leveling \% lead to increase number of plants $/ \mathrm{m}^{2}$ and consequently, improve grain germination percent (\%). In addition, it can be seen that increasing operation speed of any investigated covering system tends to decrease plants $/ \mathrm{m}^{2}$, consequently the estimated germination percent was also decreased. The highest values of germination percent $(86.9 \%)$ was accomplished using the bandwidth distributor (B) for wheat sowing, and using the rotary tiller followed by a lever for grain covering operation. While, the lowest germination percent $(70.5 \%)$ was accomplished manual wheat sowing, and using the chisel plow followed by a lever for grain covering operation.

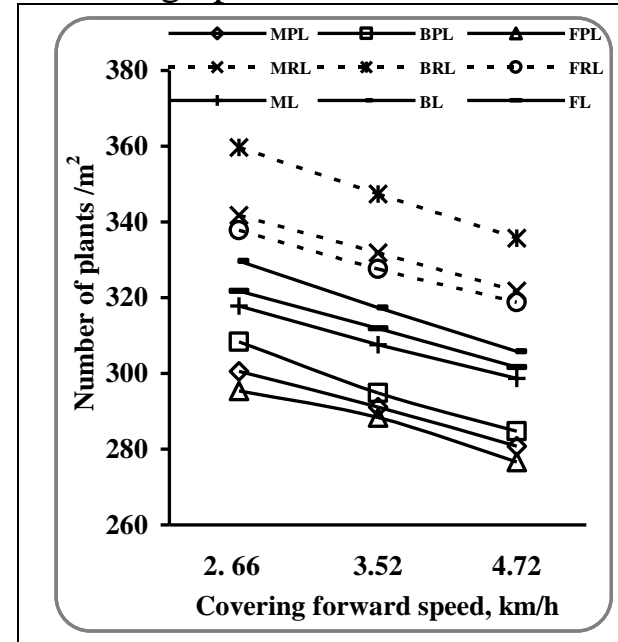

Fig. (8) the number of plants $/ \mathrm{m}^{2}$ as affected by the investigated systems

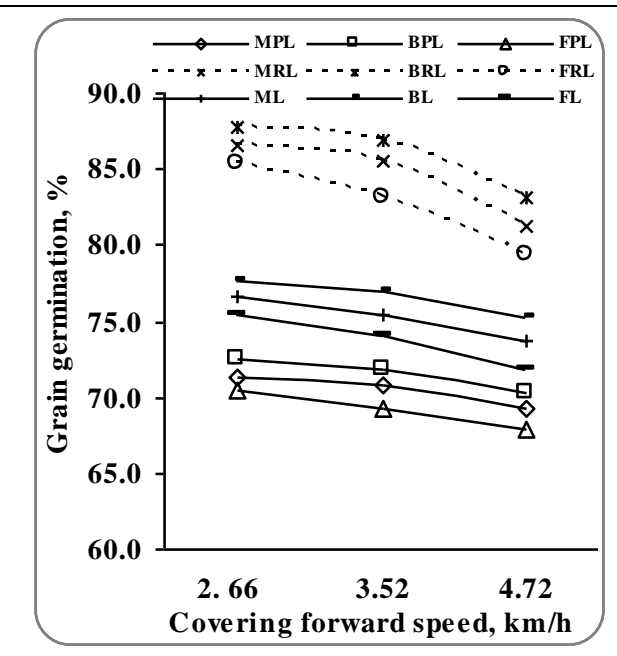

Fig. (9) the germination percent $(\%)$ due to the investigated systems

\section{- The grain yield}

Data in Fig. (10) shows the obtained grain yield (ton/fed) as affected by the investigated systems, and the speed of covering operations. 
It can be in general noticed that the highest crop grain yield was accomplished (BRL) system, which provided 2.82 ton/fed compared to the lowest grain yield (2.23 ton/fed), which provided with (MPL) On the other hand yield decrease $\%$ due to speed increasing from 2.66 to 4.72 $\mathrm{km} / \mathrm{hr}$ were :- $8.17,7.59,8.70,5.72,4.73,5.78,7.08,6.29$, and $5.72 \%$, and accomplished (MPL), (BPL), (FPL), (MRL), (BRL), (FRL), (ML), (BL), and (FL) systems respectively.

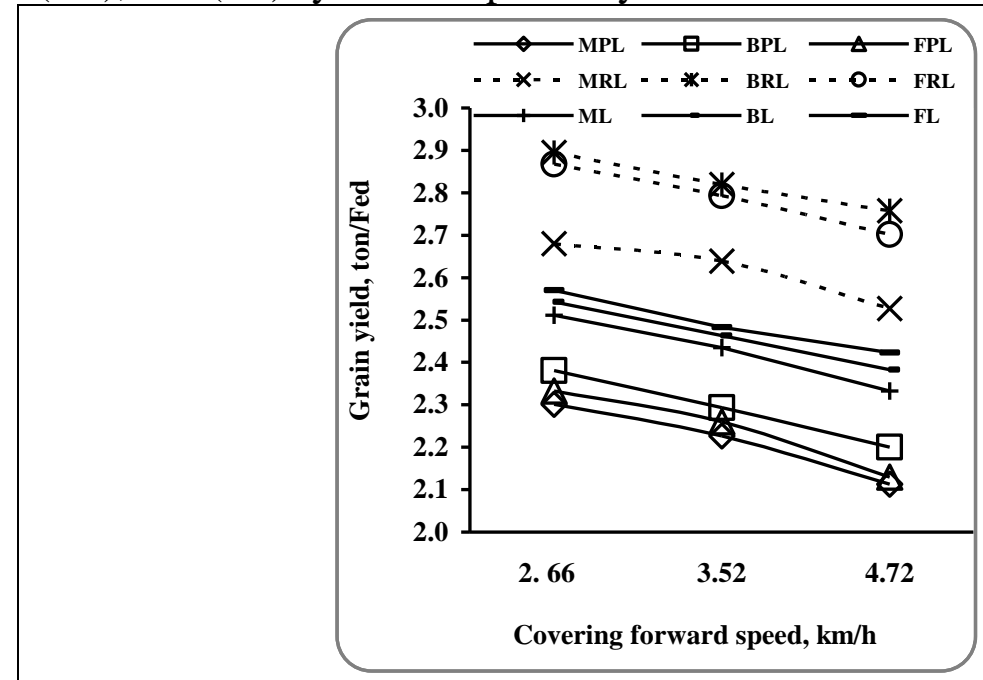

Fig. (10) Crop grain yield (ton/fed) as affected by applying the investigated systems, and the speed of covering operations.

At the average effect of covering system and speed, the manual wheat sowing gave the lowest grain yield (2.418) followed by fertilizer spreader (2,507 ton/fed) came at the end the bandwidth distributor(B), which accomplished grain yield (2.526 ton/fed)

It may be concluded that sowing with bandwidth distributor instead of manual sowing, and also replacing the rotary tiller instead of the chisel plow for grain covering operations can improve grain germination percent by about $(15 \%)$ and crop grain yield by about (26\%).

\section{3-The system energy consumptions}

The total power consumed by each investigated system at different are shown in Fig. (11) While, the energy required for each mechanized system (kW.h/fed) was estimated using equation (8) and the data are presented in Fig. (12).

Misr J. Ag. Eng., April 2009 


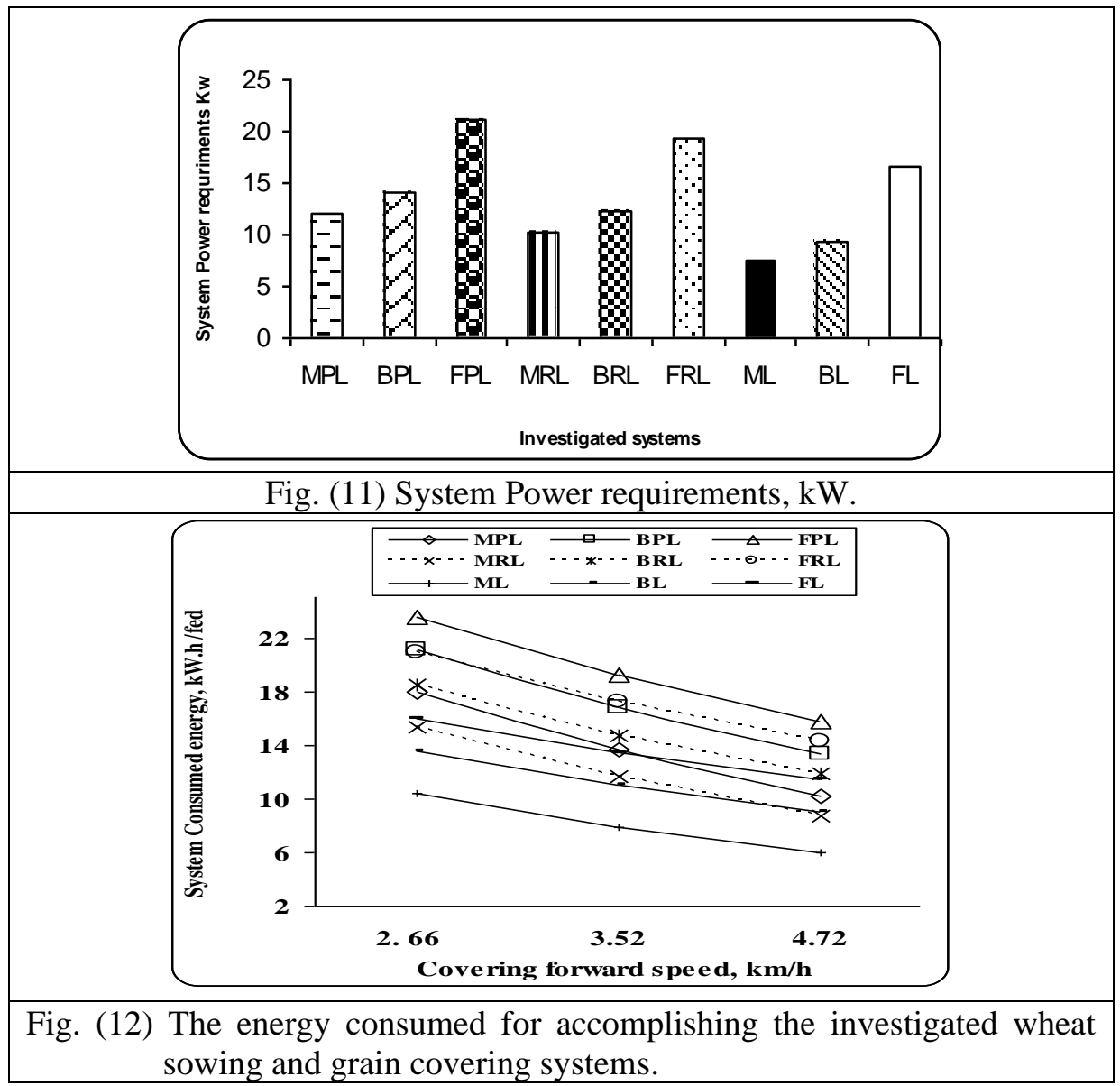

Referring Fig. (11) it can be seen that the increasing in system consumed power are mainly due to the used grain covering system. However, at average covering operation speeds the treatments using chisel plow followed by lever consumed the highest power value $(16.36 \mathrm{~kW})$. While, the treatments using rotary tiller followed by lever, and the treatments using lever only consumed 14.4, and 11.4 $\mathrm{kW}$ respectively.

The highest power requirements value was about (22 kW), and accomplished sowing with fertilizer spreader, and grain covering using chisel plow followed by lever. While, The lowest consumed power value was about $(7.6 \mathrm{~kW})$, and accomplished manual sowing, and lever covering only.

Referring Fig. (12) for the energy consumed for accomplishing the investigated systems, it can seen that the highest energy value (19.5 $\mathrm{kW} . \mathrm{h} / \mathrm{fed}$ ) was also accomplished sowing with fertilizer spreader, and Misr J. Ag. Eng., April 2009 
grain covering with chisel plow followed by lever While low consumed energy are always accomplishing manual sowing treatments. The lowest consumed energy $(8.1 \mathrm{~kW} . \mathrm{h} / \mathrm{fed})$. But it should be denoted as shown in Fig. (12) that performed the covering using rotary tiller followed by lever(L) machinery techniques demolishes the differences in the energy consumed by the system.

\section{$\underline{5 \text {-The system cost }}$}

Fig. (13) illustrates the estimated cost per fed associated the investigated wheat sowing and grain covering systems. It can be noticed that, the highest system cost value (61.1 LE/Fed) was estimated as applying system included unit distributor + rotary tiller + leveler, while. The lowest system cost value (25.08 LE/Fed) was estimated as applying system included fertilizer spreader + leveler)

The analysis of cost data revealed that, at the average of covering system the fertilizer spreader gave the highest system cost value, followed by manually sowing came at the end sowing by fertilizer spreader as the lowest cost effect. That result trend is due to the work rates accomplished by each machinery method.

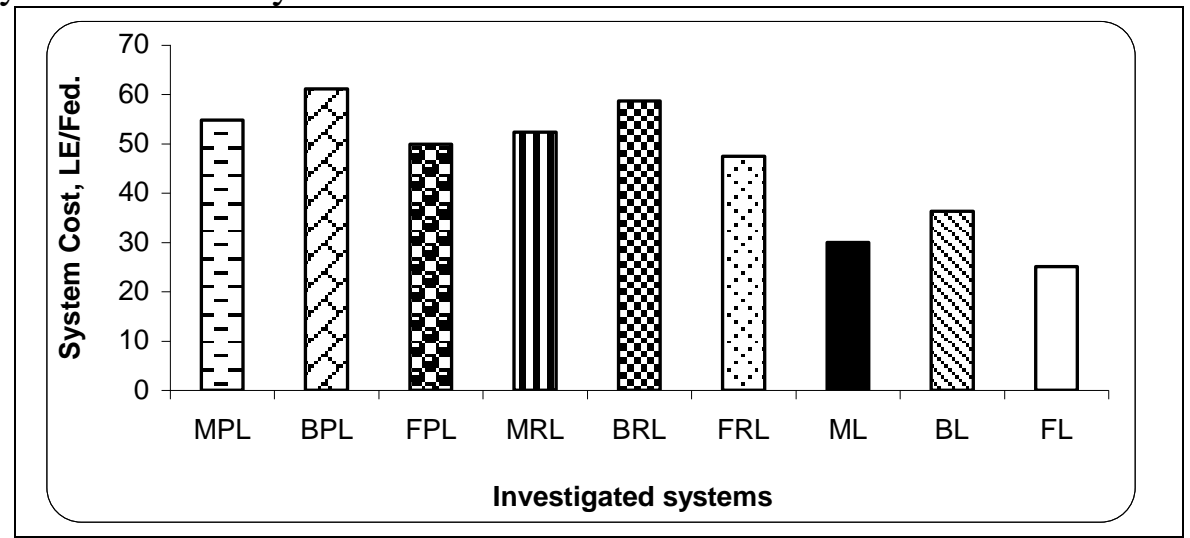

Fig. (13) The cost per fed for associated the investigated wheat sowing and grain covering systems

Logically it can be stated that covering performed using rotary tiller (R), or chisel plow $(\mathrm{P})$ each followed by lever machinery techniques have high effect on the system cost. But it should be denoted that performing covering operations at high speed, and large width will decrease cost per Misr J. Ag. Eng., April 2009 
fed, and demolish the cost differences between investigated covering systems.

\section{CONCLUSIONS}

Numerous field experiments were carried out to to select the proper mechanizing systems for sowing wheat crop in semi-arid soil. The selection was based on determining the revealed properties of top soil layer, grown plants characteristic and distribution uniformity the system energy consumptions, crop yield, and system cost.

The following conclusion may be drawn from the results of this study

* Based on the top soil layer properties, results show promises of using the bandwidth distributor (B) to perform wheat sowing, and using the rotary tiller followed by a lever to perform grain covering operation. That system revealed the lowest soil bulk values $(1.314 \mathrm{~g} / \mathrm{cm} 3)$ and the lowest soil surface roughness $(23.4 \%)$ It also resulted in the highest reduction effect of $(17.61 \%)$ in soil bulk density ,and of in soil surface roughness (25.26\%) compared to soil properties before applying the system

* Results indicated that, sowing with bandwidth distributor and covering with rotary plow lever provided the heights crop grain yield (2.834 ton /fed). It also recommended covering with rotary plow+ lever, since it leads to increase crop grain yield by about 10.3 , and $13.6 \%$, compared with covering with lever only, and chisel plow + lever respectively.

* The highest consumed energy value (19.5 kW.h/fed) was also accomplished sowing with fertilizer spreader, and grain covering with chisel plow followed by lever While low consumed energy are always accomplishing manual sowing treatments. The lowest consumed energy $(8.1 \mathrm{~kW} . \mathrm{h} / \mathrm{fed})$. But it should be denoted that performed the covering using rotary tiller followed by lever (L) machinery techniques demolishes the differences in the energy consumed by the system compared to manual

* The highest system cost value $(61.1 \mathrm{LE} / \mathrm{Fed})$ was estimated as applying system included unit distributor + rotary tiller + leveler, while. The lowest system cost value (25.08 LE/Fed) was estimated as applying system included fertilizer spreader + leveler)

Misr J. Ag. Eng., April 2009 


\section{REFERENCES}

Abdel-Maksoud, S. E.; M. K. Abdel-Wahab, and F. Z. Ahmed (1994). Effect of farm operation and machine weight on some physical properties. Misr J. of Agr. Eng. Vol. 11(2): 197-209.

Abdel-Wahab, M. K. (1994). Minimum tillage by a simple combination. Misr J. of Agr. Eng. Vol. 11 (3): 711-723.

Abdou, F. M. E. (1996). Effect of some grainbed preparation systems and mechanical planting on wheat production. Misr J. of Agr. Eng. 13(1): 44-58.

Abo El-khier, M.M. and E. A.M. Abdel Ghafar (1985). Performance evaluation of locally made combined tillage machine. Misr J. of Agr. Eng. Vol. 2(4):3-17.

Abo El-Naga, M.H. (2006). Development of a distribution unit for sowing small grains by air system. J. Agric. Sci. Mansoura Unvi., 31(7): 143-158, 2006.

Black, C.A. (1965). Methods of soil analysis. Part 1, Physical and Mineralogical Properties, Argon. No. (9) A.S.A., Inc., Madison, Wisc., U.S.A.

Coates, W. (1992). Performance evaluation of a pendulum spreader. Trans. ASAE, 8 (3): $285-288$.

El-Sayed, G.H. (1983). Mechanized techniques for suitable grain-bed preparation and planting of maize. M. Sc. Thesis, Agric. Eng. Dept., Fac. of Agric., Zagazig Univ.

El-Saharigi, A.F; G.H. El-Sayed; S.E. Badr and I. Yehia (2001). Effect of some planting and land leveling systems on barely-crop productivity. 9th Conference of Misr Society of Agric. Eng., 9-11 September 2001: 133 - 146.

Essam, H.E. (1997). Influence of precision system and planting method on barley yield. Conference of Misr Society of agric. Eng. $9^{\text {th }}$ sept. 1997. Misr J. of Agr. Eng. Vol. 4(4):221-223.

Gaheen, S.A.; M.M. Metwalli and S.M. Sharaf (1978). Effect of plowing speeds on some soil physical and mechanical properties. J. Agric. Res. Tanta Univ. 4 (2). 
Helmy, M.; S.M. Gomaa; H.M. Sorour and H.A. El-khateeb (2001). Effect of some different grainbed preparation systems on irrigation water consumption and corn yield. Misr J. of Agr. Eng. Vol. 18(1): 169 - 181.

Heege, H.J. (1986). An forderungen an die Saatgutablage.VDI/MEG-Tagung Giessen,Heft 3 (Bodenbearbeitung und Saat), VDI/fuchgruppe Landtechnik ,DÜSSe.ldorf 1,Germany: 55-76.

Hunt, D. (1983). Farm power and machinery management 8 th Ed., Iowa state Univ., Ames, U. S. A.

Kienzle, J. (2006). Farm power and mechanization for small farms in sub-Saharan Africa. Food and agriculture organization of the United Nations Rome.

Kishta, A.M. and A.A. Eliwa (2005). Developed and performance evaluation of a local grain and fertilizer spreader. 13 th Annual Conference of the Misr Society of Agric. Eng., 14-15 December 2005.

Moussa, A.I.M. (1987). Study the usability of different combine machines in wheat and rice fields. M. Sc. Thesis, Agric. Eng. Dept., Fac. Of Agric., Zagazig. Univ.

Morad, M.M; W.M. Mechail and A.A. Sayedahmad (2002). Development of a simulation model of the spinning disc performance in the broadcaster fertilizer spreader. Misr J. of Agr. Eng. Vol. 19(4):945- 957.

Maksoud, S.E. (1975). The effect of deep tillage on weed control in field in relation to soil physical properties. Zagazig, J. of Ag. Res. 2:391- 403.

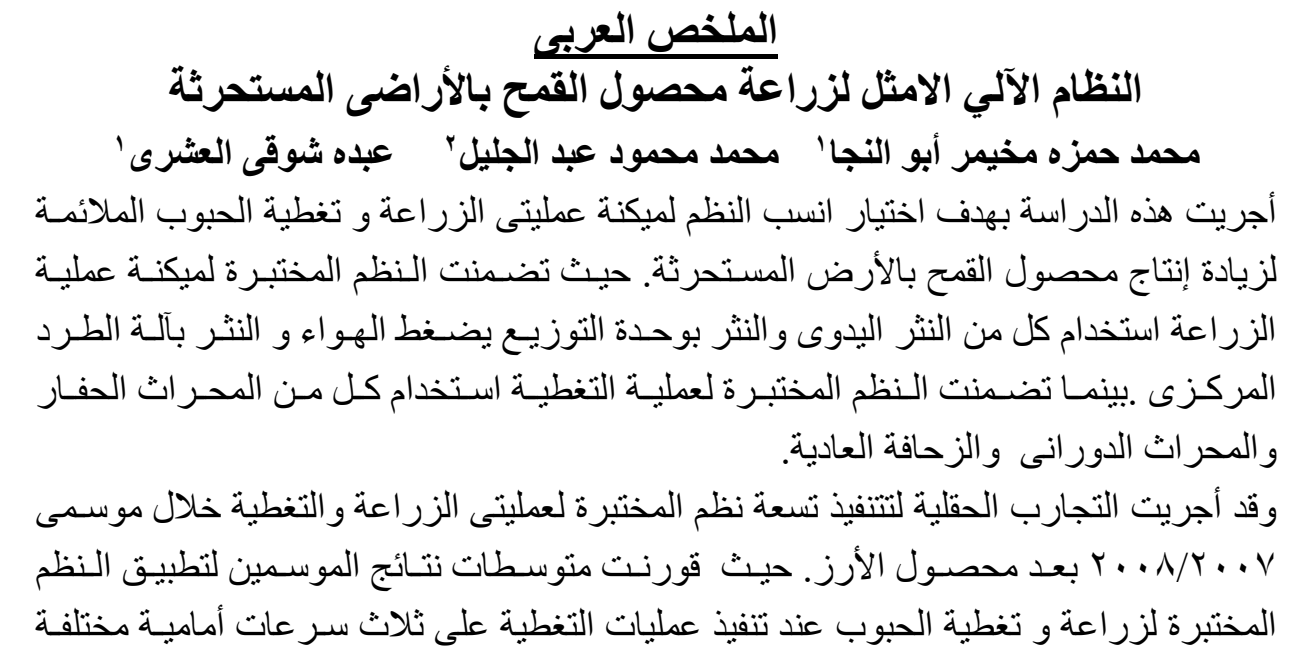

Misr J. Ag. Eng., April 2009 
وذللك على ضوء تحديد مدى تأثر صفات التربة لتطبيق كل نظسام ونسبة الإنبات و الإنتاجيـة و

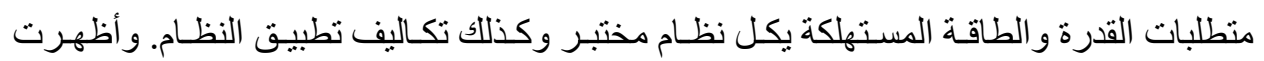
النتائج التجريبية لتطبيق الأنظمة حقليا ما يأتي :

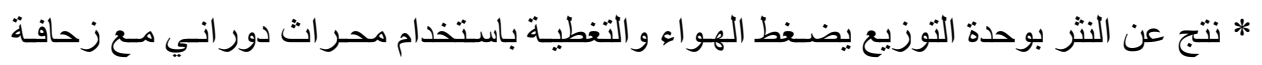

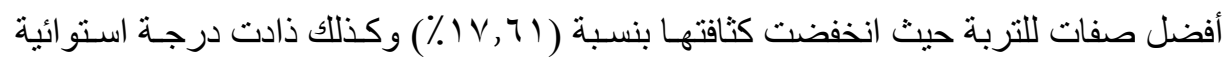

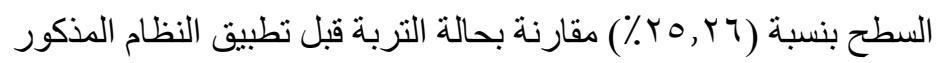

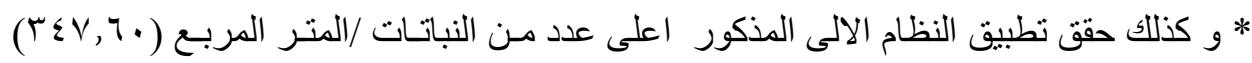

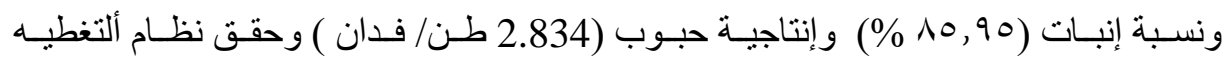

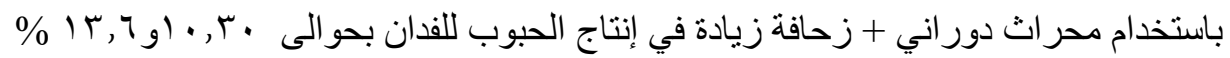

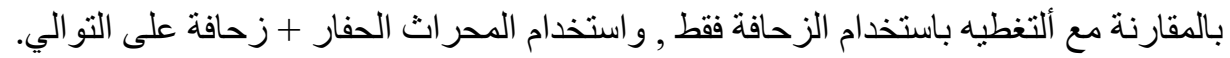

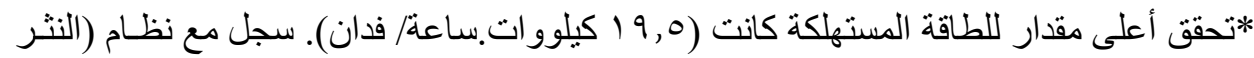

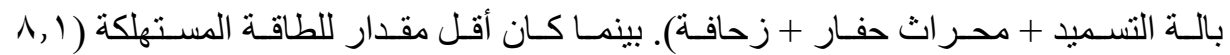

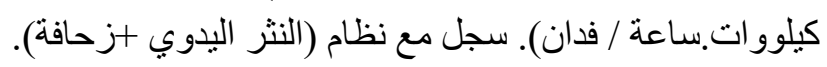

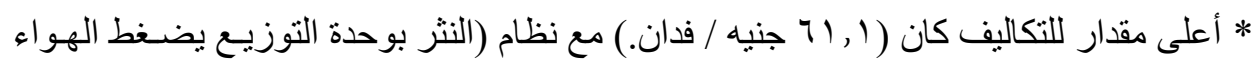

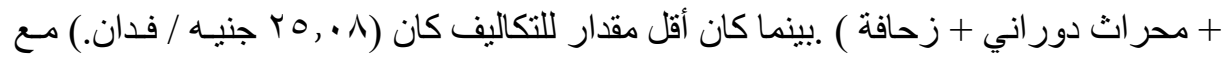
نظام (النثر بالة التسميد + زحافة). 